\title{
Modal Sosial Kognitif dalam Pengelolaan Parak dan Rimbo di Sumatera Barat
}

Ferdinal Asmin

Dinas Kehutanan Provinsi Sumatera Barat, Jalan Raden Saleh Nomor 8A, Padang, Indonesia

*e-mail: dishut@sumbarprov.go.id

\section{Abstract / Abstrak}

The cognitive elements of social capital need to be elaborated to understand the community-based forest management, such as the practice of parak and rimbo in the Koto Malintang and Simancuang communities. This study aims to identify and describe these cognitive elements. The research method used was case study method with constructivism paradigm. The data was collected using interview, observation, and document review techniques. Cognitive social capital can be developed through local ecological knowledge that has become part of Minangkabau customs and culture. The results showed that cognitive elements in the form of norms, values, beliefs and attitudes can describe how the community plans, utilizes, and controls the forest resource management. The identification of these cognitive elements shows that people pay attention to the principles of sustainability, justice, ability, security, profit, opportunity, and well-being.

Elemen-elemen kognitif dari modal sosial perlu dielaborasi untuk memahami pengelolaan hutan berbasis masyarakat, seperti praktik parak dan rimbo pada masyarakat Koto Malintang dan Simancuang. Penelitian ini bertujuan untuk mengidentifikasi dan menggambarkan elemen-elemen kognitif tersebut. Metode penelitian menggunakan metode studi kasus dengan mengikuti paradigma konstruktivisme. Pengumpulan data menggunakan teknik wawancara, observasi, dan kajian dokumen. Modal sosial kognitif dapat dibangkitkan dari pengetahuan ekologis lokal yang telah menjadi bagian dari adat dan budaya Minangkabau. Hasil penelitian menunjukkan bahwa elemen-elemen kognitif berupa norma, nilai, keyakinan, dan sikap dapat menggambarkan bagaimana masyarakat merencanakan, memanfaatkan, dan mengendalikan pengelolaan sumber daya hutan. Identifikasi elemen kognitif tersebut menunjukkan bahwa masyarakat memperhatikan prinsip-prinsip kelestarian, keadilan, kemampuan, keamanan, keuntungan, kesempatan, dan kesejahteraan.
Keywords / Kata kunci

Norms;

Values;

Beliefs;

Attitudes;

Forest management

\section{Pendahuluan}

Kajian modal sosial bukanlah sesuatu hal yang baru, meskipun baru mendapatkan perhatian mendalam dari berbagai peneliti dalam 25 tahun terakhir. Modal sosial sebagai sebuah konsep telah dikaji untuk menjelaskan capaian kinerja pengelolaan sumber daya hutan (Gibson dkk., 1999; Roslinda dkk., 2017; Gorriz-Mifsud dkk., 2017), bahkan mobilisasi modal sosial dinilai penting sebelum membangun kesepakatan pengelolaan hutan bersama masyarakat (Magno, 2001; GorrizMifsud dkk., 2017). Banyak pula penelitian yang telah mempertegas peran modal sosial dalam pengelolaan hutan.

Kecenderungan penelitian modal sosial dalam pengelolaan hutan lebih mengarah pada pendekatan kuantitatif dalam sepuluh tahun terakhir. Banyak peneliti tertarik untuk mengukur modal sosial dalam ukuran-ukuran kuantitatif. Fokus pengukuran modal sosial diantaranya adalah jaringan sosial (GarcíaAmado dkk., 2012; Borg dkk., 2015; Yamaki, 2016), perspektif aktor dan publik (Ekawati \& Nurrochmat, 2014), dan kelembagaan lokal (Szulecka \& Secco, 2014). Pengukuran modal sosial yang lebih kompleks juga dilakukan, yang meliputi grup dan jaringan, kepercayaan dan solidaritas, tindakan kolektif dan kerja sama, kohesi dan inklusi sosial, informasi dan komunikasi, serta pemberdayaan aksi politik (Nath dkk., 2010; Nababan dkk., 2016).

Penelitian-penelitian tersebut lebih cenderung membahas aspek relasi, sementara 
aspek sistem masih belum tergali secara mendalam. Modal sosial bukan hanya mencakup aspek relasi melainkan juga aspek sistem (Esser, 2008). Kajian modal sosial seharusnya bukan hanya persoalan mengukur modal sosial (Chaskin dkk., 2006; Payne dkk., 2011; Teilmann, 2012) melainkan juga harus lebih menekankan pada upaya memahami dan menggambarkan modal sosial dalam konteks pengelolaan sumber daya alam dan lingkungan secara komprehensif dan holistik. Hal ini diperlukan untuk mencapai kekonkritan, menjelaskan hubungan kausal, menjadi konsep analitis, dan mampu mencirikan modalnya (Castiglione, 2008). Untuk itu, kajian modal sosial juga perlu mencakup aspek-aspek keberadaan manusia (baik sebagai individu atau kelompok) dalam hubungannya dengan lingkungan alam yang memiliki konsekuensi penting bagi masyarakat itu sendiri dan lingkungan alamnya, sehingga diperlukan kajian sosiologis dan psikologis secara mendalam.

Pemahaman aspek sistem dari modal sosial dapat dilakukan dengan mengelaborasi elemenelemen modal sosial secara rinci. Elemen modal sosial dikategorikan menjadi dua, yaitu kognitif dan struktural (Uphoff, 2000; Van Rijn dkk., 2012; Ramón-Hidalgo dkk., 2018). Kategori kognitif mencakup norma, nilai, sikap, dan keyakinan, sedangkan kategori struktural mencakup peran, aturan, preseden, prosedur, dan jejaring. Elemen-elemen tersebut mencirikan modal sosial dalam pengelolaan sumber daya alam (Asmin, 2018). Elaborasi modal sosial kognitif perlu dilakukan karena modal sosial kognitif merupakan akumulasi sumber daya dalam bentuk norma, nilai, keyakinan, dan sikap yang melandasi terbentuknya modal sosial struktural untuk mengkoordinasikan aksi-aksi kolektif yang saling menguntungkan dalam pengelolaan sumber daya alam. Elaborasi elemen-elemen modal sosial tersebut dapat memungkinkan berbagai pihak untuk memahami fenomena pengelolaan hutan berbasis masyarakat.
Penelitian ini bertujuan mengidentifikasi dan menggambarkan elemen-elemen modal sosial dalam kategori kognitif, atau disebut dengan modal sosial kognitif. Kajian ini dinilai penting karena elemen-elemen modal sosial kognitif tersebut merasionalisasi elemenelemen modal sosial struktural (Uphoff, 2000; Liang dkk., 2015; Asmin, 2018). Modal sosial kognitif dapat meningkatkan kualitas relasi dan keterlibatan masyarakat dalam suatu sistem sosial (Ansari dkk., 2012; Felício dkk., 2014; Ortiz dkk., 2016). Penelitian ini juga menarik karena elemen modal sosial kognitif diamati pada praktik kelola hutan berbasis masyarakat berupa parak dan rimbo yang lazim dilakukan oleh masyarakat Minangkabau di Provinsi Sumatera Barat. Parak adalah wilayah berhutan dengan pola agroforestry yang berfungsi untuk perlindungan dan produksi, sedangkan rimbo adalah wilayah berhutan yang berfungsi sebagai hutan cadangan dan hutan larangan (Michon dkk., 1986; von Benda-Beckmann, 2013; Asmin dkk., 2017).

Dalam perspektif Psikologi Lingkungan, hubungan perilaku masyarakat Minangkabau dengan lingkungan alamnya dapat tergambarkan dari praktik parak dan rimbo, sesuai dengan pepatah adat "alam terkembang jadikan guru (alam takambang jadikan guru)" yang menjadi filosofi masyarakat Minangkabau. Sebagai perwujudan dari filosofi tersebut, parak dan rimbo adalah dua entitas bentuk lahan yang harus ada dalam penataan ruang wilayah nagari (desa) bagi masyarakat Minangkabau (Kosasih, 2013; Safitri dkk., 2016; Hermayulis, 2002). Praktik parak dan rimbo telah menjadi kebiasaan masyarakat Minangkabau dalam pengelolaan lahan, utamanya dalam budidaya pertanian. Oleh karena segala perbuatan atau pekerjaan harus bersesuaian dengan adat dan agama, maka praktik parak dan rimbo tidak dapat dilepaskan dari pedoman "adat bersendikan syariat, syariat bersendikan Kitabullah (adaik basandi syara', syara' basandi Kitabullah)". Masyarakat Minangkabau, yang dikenal sebagai komunitas muslim dengan karakter adat yang masih kuat, 
masih menerapkan pengelolaan parak dan rimbo tersebut dalam pengelolaan sumber daya lahan di wilayah nagari (Stark, 2014; Tono dkk., 2019; Firdaus, 2019; Eric, 2019).

\section{Metode}

\section{Pendekatan penelitian}

Praktik kelola hutan berbasis masyarakat yang melekat dalam struktur sosial masyarakat merupakan realitas sosial yang dikonstruksikan oleh masyarakat itu sendiri sesuai dengan pengetahuan dan kearifan lokal yang dimilikinya. Oleh karena itu, penelitian ini mengikuti paradigma konstruksionis sosial atau konstruktivisme yang mempersyaratkan adanya interaksi dialektif antara peneliti dan subjek yang diteliti (Guba \& Lincoln, 1994; Amineh \& Asl, 2015; Adom dkk., 2016). Sementara itu, pemaknaan terhadap elemen-elemen modal sosial kognitif dilakukan dengan pendekatan hermeneutik dengan memberikan empati, intensionalitas, dan interpretasi terhadap pernyataan dan tindakan subjek atau pelaku (Suharjito, 2014). Metode yang digunakan adalah metode studi kasus dengan mengamati praktik-praktik kelola hutan yang dilakukan masyarakat Koto Malintang dan masyarakat
Simancuang.

\section{Waktu dan lokasi penelitian}

Penelitian ini dilakukan sejak bulan Juli 2015 sampai dengan bulan Agustus 2016. Dua komunitas yang diamati adalah masyarakat Koto Malintang di Kabupaten Agam dan masyarakat Simancuang di Kabupaten Solok Selatan. Kedua komunitas tersebut mengembangkan pengelolaan sumber daya hutan berdasarkan pengetahuan ekologis lokal (local ecological knowledge) dengan kekuatan budaya Minangkabau (Asmin dkk., 2016; Asmin dkk., 2017). Kedua komunitas tersebut juga telah ditetapkan sebagai nagari peduli kehutanan yang diakui di tingkat provinsi dan nasional serta dapat menjadi representasi dari masyarakat Minangkabau yang sangat dominan di Provinsi Sumatera Barat.

\section{Pengumpulan data dan analisis}

Pengumpulan data dilakukan dengan wawancara tak terstruktur, observasi, dan kajian dokumen. Wawancara tak terstruktur memungkinkan peneliti untuk menggali fokus penelitian secara mendalam (Qu \& Dumay, 2011; Wilson, 2012). Observasi digunakan untuk mengamati perilaku sehari-hari masyarakat berkaitan dengan fokus penelitian

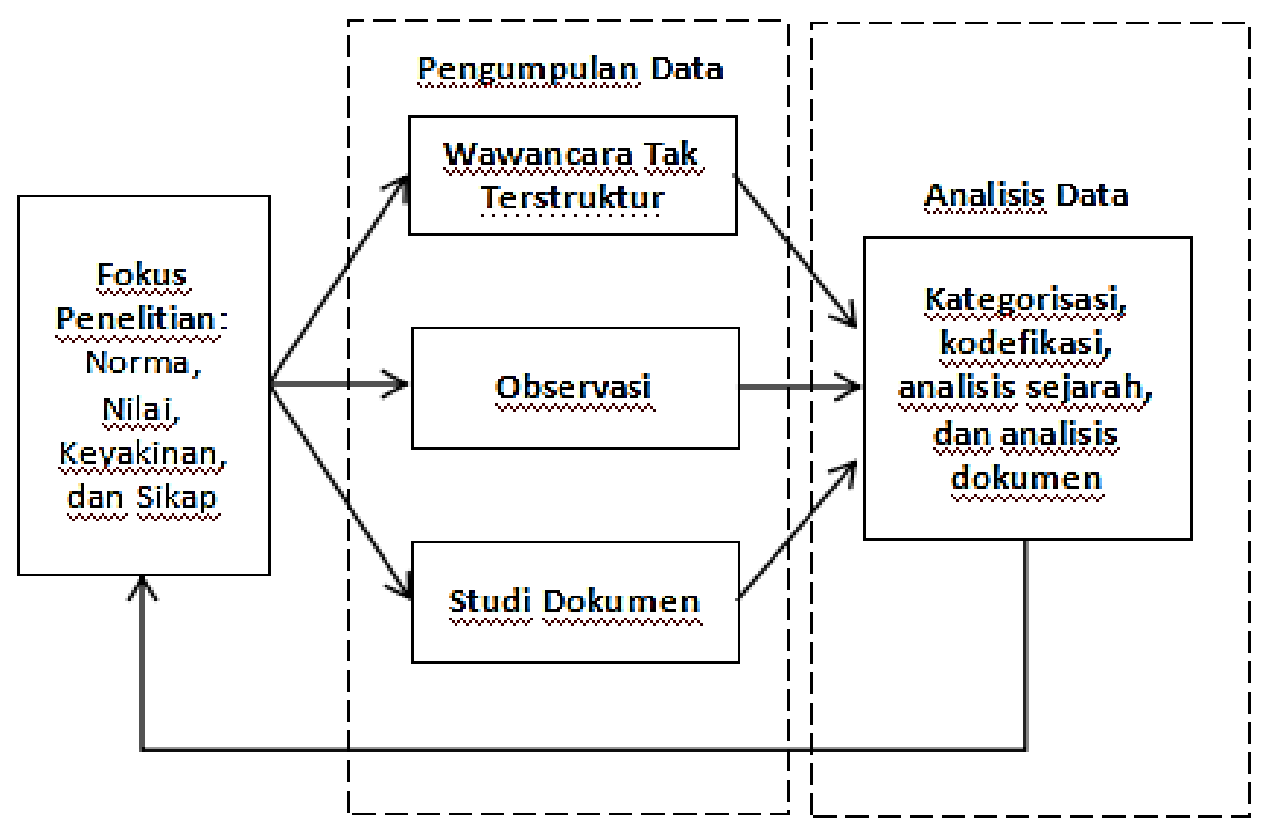

Gambar 1. Alur penelitian modal sosial kognitif 
(Oun \& Bach, 2014; Koskei \& Simiyu, 2015). Sementara itu, kajian dokumen digunakan untuk melengkapi informasi dari wawancara dan observasi yang telah dilakukan (Owen, 2014; Moravcsik, 2014).

Wawancara dilakukan dengan 20 informan kunci, yaitu 2 orang Ketua Kerapatan Adat Nagari/ KAN, 2 orang Wali Nagari (Kepala Desa), 3 orang Wali Jorong (Kepala Dusun), 5 orang kepala suku/ kaum, 6 orang tokoh masyarakat, dan 2 orang tenaga pendamping masyarakat. Observasi dilakukan melalui pengamatan perilaku sehari-hari masyarakat, baik individual maupun kelompok. Dokumendokumen yang dikaji berupa peraturan, laporan, buku, dan foto dokumentasi.

Analisis data menggunakan kategorisasi dan kodefikasi yang dilengkapi dengan analisis sejarah dan analisis dokumen. Kategorisasi dan kodefikasi dilakukan untuk mengklasifikasikan data dalam elemen-elemen modal sosial sebagaimana dirumuskan oleh Uphoff (2000). Definisi operasional dari masing-masing elemen modal sosial kognitif dijelaskan pada tabel 1 dan alur penelitian sebagaimana diilustrasikan pada gambar 1. Elaborasi elemenelemen tersebut dikategorikan menurut prinsip kelestarian, keadilan, kemampuan, keamanan, keuntungan, kesempatan, dan kesejahteraan. Prinsip-prinsip tersebut dirangkum dari konsep livelihoods yang dikembangkan Chambers dan Conway (1992) dan Chambers (1995) serta domain modal sosial menurut Forrest dan
Kearns (2001). Untuk melengkapi analisis, bukti-bukti pantun yang dituliskan Rangkoto (1982) dijadikan sebagai sumber karena kebiasaan masyarakat Minangkabau menggunakan pantun dalam menjelaskan setiap perilaku yang berkembang di masyarakat.

Modal sosial kognitif berkembang dari pengetahuan ekologis lokal yang tertanam dan dibagikan dari generasi ke generasi (Lauer \& Aswani, 2009; Mistry \& Berardi, 2016) dan merupakan akumulasi pengetahuan masyarakat tentang hubungan dengan sesama dan dengan lingkungannya (Charnley dkk., 2008; Bussey dkk., 2016). Berdasarkan pengetahuan ekologis lokal, masyarakat memiliki pengetahuan praktis sebagai kognisi instrumental dalam mengelola sumber daya alam dan biasanya melakukan proses konseptualisasi (mental processes) untuk menghasilkan ide-ide kognisi normatif berupa norma, nilai, sikap, dan keyakinan, yang diperkuat oleh budaya dan ideologi (Uphoff, 2000).

\section{Hasil}

\section{Norma}

Hasil penelitian mengelompokkan norma dalam kategori perencanaan, pemanfaatan, dan pengendalian parak dan rimbo sebagaimana disajikan pada tabel 2. Norma-norma tersebut meliputi prinsip kelestarian, keadilan, kemampuan, keamanan, keuntungan, kesempatan, dan kesejahteraan.

Tabel 1

Definisi Operasional dari Elemen-elemen Modal Sosial Kognitif

\begin{tabular}{ll}
\hline \multicolumn{1}{c}{ Elemen } & \multicolumn{1}{c}{ Definisi Operasional } \\
\hline Norma & $\begin{array}{l}\text { Pemahaman informal yang menata perilaku individu atau kelompok masyarakat dalam } \\
\text { merencanakan, memanfaatkan, dan mengendalikan parak dan rimbo. }\end{array}$ \\
Nilai & $\begin{array}{l}\text { Hal-hal yang dianggap penting dalam merencanakan, memanfaatkan, dan mengendalikan } \\
\text { parak dan rimbo. }\end{array}$ \\
Keyakinan & $\begin{array}{l}\text { Hal-hal yang dianggap benar dalam merencanakan, memanfaatkan, dan mengendalikan } \\
\text { parak dan rimbo. }\end{array}$ \\
& $\begin{array}{l}\text { Ekspresi terhadap perencanaan, pemanfaatan, dan pengendalian parak dan rimbo } \\
\text { Sikap }\end{array}$
\end{tabular}


Dalam kategori perencanaan, informan menyampaikan bahwa parak dan rimbo menjamin kelangsungan hidup generasi mereka saat ini dan masa yang akan datang. Mereka kemudian telah melakukan pembagian parak dan rimbo menurut ulayat kaum atau suku yang ada dalam suatu wilayah atau nagari dengan batas yang jelas, baik buatan maupun alami. Pembagian ini diwariskan secara turun-temurun dari generasi ke generasi dalam suatu keluarga, kaum, dan suku. Bagi masyarakat Koto Malintang, seluruh parak dan rimbo merupakan harta pusaka tinggi, sedangkan bagi masyarakat Simancuang, ada parak dan rimbo yang kemudian merupakan harta pusaka rendah. Namun demikian, parak dan rimbo bukanlah barang komoditas yang dengan mudah diperjualbelikan. Hal ini diperkuat oleh keterangan informan sebagai berikut:

"Misalnya kemenakan kami ada tiga orang perempuan, jika disertifikat oleh si A, bagaimana dengan si B dan si C. Oleh karena itu, lahan tidak bisa dijual sembarangan...parak dikelola bersama, sawah dikelola secara bergantian..."

"...Pusaka tinggi itu turun temurun kepada perempuan, ada pusaka rendah, hasil kerja keluarganya, bukan warisan

Tabel 2

Norma dalam Perencanaan, Pemanfaatan, dan Pengendalian Parak dan Rimbo

\begin{tabular}{|c|c|c|c|}
\hline Prinsip & Perencanaan & Pemanfaatan & Pengendalian \\
\hline Kelestarian & $\begin{array}{l}\text { Parak dan rimbo untuk } \\
\text { menjamin kelangsungan } \\
\text { hidup dari generasi ke } \\
\text { generasi (anak } \\
\text { kemenakan) }\end{array}$ & $\begin{array}{l}\text { Rimbo adalah hutan belantara } \\
\text { yang berfungsi perlindungan } \\
\text { (rimbo larangan) dan } \\
\text { produksi (rimbo cadangan), } \\
\text { sedangkan parak adalah lahan } \\
\text { vegetasi seperti rimbo yang } \\
\text { merupakan campuran } \\
\text { tanaman musiman dan } \\
\text { tahunan (juga berfungsi } \\
\text { lindung dan produksi) }\end{array}$ & $\begin{array}{l}\text { Dapat diusahakan secara terus- } \\
\text { menerus oleh anak kemenakan } \\
\text { dari generasi ke generasi }\end{array}$ \\
\hline Keadilan & $\begin{array}{l}\text { Pembagian sumber daya } \\
\text { lahan (parak dan rimbo) } \\
\text { menurut hak ulayat kaum } \\
\text { dan suku }\end{array}$ & $\begin{array}{l}\text { Lahan (parak dan rimbo) } \\
\text { dikelola oleh pihak } \\
\text { perempuan, tapi dapat juga } \\
\text { dikelola pihak laki-laki } \\
\text { dengan persetujuan niniak } \\
\text { mamak }\end{array}$ & $\begin{array}{l}\text { Semua anak kemenakan } \\
\text { berhak mendapatkan hak } \\
\text { kelola atas lahan parak dan } \\
\text { rimbo }\end{array}$ \\
\hline Kemampuan & $\begin{array}{l}\text { Dimulai dari lahan milik } \\
\text { keluarga, paruik, kaum, } \\
\text { suku, dan nagari }\end{array}$ & $\begin{array}{l}\text { Mengelola sesuai dengan } \\
\text { kemampuan (sekitar .5-1 } \\
\text { ha) }\end{array}$ & $\begin{array}{l}\text { Semua lahan terolah dan tidak } \\
\text { terlantar (biasanya ditentukan } \\
\text { dalam jangka waktu tertentu) }\end{array}$ \\
\hline Keamanan & $\begin{array}{l}\text { Pengakuan tanah ulayat } \\
\text { jelas dengan kemantapan } \\
\text { batas parak dan rimbo }\end{array}$ & $\begin{array}{l}\text { Pemanfaatan lahan dalam } \\
\text { bentuk campuran tanaman } \\
\text { tahunan dan tanaman } \\
\text { musiman serta mampu } \\
\text { mengantisipasi kerusakan } \\
\text { (bencana) }\end{array}$ & $\begin{array}{l}\text { Tidak ada pelanggaran batas } \\
\text { hak dan tidak terjadi bencana } \\
\text { alam (terutama banjir dan } \\
\text { tanah longsor) }\end{array}$ \\
\hline Keuntungan & $\begin{array}{l}\text { Parak dan rimbo bukan } \\
\text { barang komoditas dan } \\
\text { perpindahan hak kelola } \\
\text { diatur niniak mamak }\end{array}$ & $\begin{array}{l}\text { Dapat menghasilkan } \\
\text { pendapatan untuk memenuhi } \\
\text { kebutuhan keluarga, kaum, } \\
\text { suku, dan nagari }\end{array}$ & $\begin{array}{l}\text { Tidak ada kerugian dalam } \\
\text { mengelola lahan (minimal } \\
\text { mampu memenuhi kebutuhan } \\
\text { keluarga) }\end{array}$ \\
\hline Kesempatan & $\begin{array}{l}\text { Hak kelola menurut garis } \\
\text { keturunan ibu } \\
\text { (matrilineal) dan hak } \\
\text { kuasa oleh niniak mamak }\end{array}$ & $\begin{array}{l}\text { Menghasilkan aneka ragam } \\
\text { produk untuk kebutuhan } \\
\text { keluarga dan pasar }\end{array}$ & $\begin{array}{l}\text { Adanya kemudahan dalam } \\
\text { mengelola lahan menurut } \\
\text { sistem hukum adat dan hukum } \\
\text { negara }\end{array}$ \\
\hline Kesejahteraan & $\begin{array}{l}\text { Mengatur kesejahteraan } \\
\text { seluruh anak kemenakan } \\
\text { dari generasi ke generasi }\end{array}$ & $\begin{array}{l}\text { Hasil bersama dan hasil } \\
\text { keluarga (pribadi) serta } \\
\text { pengaturan bunga (iuran) } \\
\text { pemanfaatan }\end{array}$ & $\begin{array}{l}\text { Adanya peningkatan } \\
\text { penghasilan keluarga } \\
\text { (terpenuhinya kebutuhan } \\
\text { ekonomi keluarga) }\end{array}$ \\
\hline
\end{tabular}

Sumber: hasil wawancara dan pengamatan lapangan tahun 2015 sampai 2016 serta dikembangkan dari Rangkoto (1982) 
dari nenek moyang, misalnya saya berkeluarga saya memiliki hasil sawah diwariskan ke anak laki-laki dan perempuan, tapi kalau didapatkan dari nenek moyang itu harus ke anak perempuan. Karena masing-masing suku sudah mempunyai tanah dari nenek moyang tanah ulayat namanya"

Perpindahan hak diatur oleh kepala kaum/ suku (panghulu/ niniak mamak). Hak kelola terhadap parak dan rimbo dipertimbangkan menurut garis keturunan ibu (matrilineal) dan hak kuasa tetap melekat pada niniak mamak. Parak dan rimbo harus mendatangkan kesejahteraan bagi seluruh anak nagari (dari keluarga, kaum, dan suku) secara berkesinambungan.

Informan menyatakan bahwa lahan budidaya dikelola menurut silsilah keluarga dari pihak perempuan, namun demikian bukan berarti keluarga dari pihak laki-laki tidak boleh mengelola lahan. Bila disetujui oleh panghulu atau niniak mamak dan pihak perempuan, pihak laki-laki dapat mengelola lahan. Bagi masyarakat Koto Malintang, lahan yang dikelola oleh pihak laki-laki disebut dengan parak pambujangan, sedangkan bagi masyarakat Simancuang, lahan budidaya dapat dikelola oleh pihak perempuan maupun lakilaki.

Kemampuan mengelola lahan parak dan rimbo berkisar antara .5-1 hektar menurut sejumlah informan. Lahan kelola pada umumnya ditanami aneka tanaman kehutanan, perkebunan, dan pertanian. Jenis tanaman komersial yang dibudidayakan adalah durian, kulit manis, surian, bayur, karet, kopi, dan kakao.

Mekanisme untuk mendukung norma dielaborasi lebih mendalam menurut konsep

Tabel 3

Mekanisme Pendukung Norma Masyarakat dalam Pengelolaan Parak dan Rimbo

\begin{tabular}{|c|c|}
\hline $\begin{array}{l}\text { Mekanisme } \\
\text { Pendukung }\end{array}$ & Uraian \\
\hline Meta norma & $\begin{array}{l}\text { Budaya malu sebagaimana pantun adat yang berbunyi jokok tasabuik di nan salah } \\
\text { manaruah malu badan diri kalau tasabuik di nan bana sananglah hati niniak mamak } \\
\text { sarato nan hadia kasadonyo (jika melakukan kesalahan, seseorang akan merasa malu, jika } \\
\text { melakukan kebaikan, senanglah hati niniak mamak dan seluruh anggota masyarakat yang } \\
\text { melihatnya). }\end{array}$ \\
\hline Dominansi & $\begin{array}{l}\text { Masyarakat dari suku Koto, Tanjuang, Sikumbang, dan Pili (suku nan ampek) } \\
\text { mendominasi pengambilan keputusan di Koto Malintang, sedangkan masyarakat dari } \\
\text { Muaro Labuah mendominasi pengambilan keputusan di Simancuang. }\end{array}$ \\
\hline Internalisasi & $\begin{array}{l}\text { Prosesnya dimulai dari keluarga inti, keluarga besar (saparuik), kaum, suku, dan sampai } \\
\text { ke tingkat nagari. Media internalisasi dapat berupa pepatah petitih, pengajian di surau- } \\
\text { surau, dialog di warung-warung (lapau), dan acara-acara tradisi. }\end{array}$ \\
\hline Pencegahan & $\begin{array}{l}\text { Sistem matrilineal, pewarisan hak atas lahan menurut garis keturunan perempuan, dan } \\
\text { sulitnya pengalihan hak atas lahan ke pihak luar. }\end{array}$ \\
\hline Bukti sosial & $\begin{array}{l}\text { Pemanfaatan lahan sesuai dengan ulayat suku masing-masing atau mendapatkan izin dari } \\
\text { panghulu atau niniak mamak dan tradisi-tradisi masih dijalankan sampai saat ini. }\end{array}$ \\
\hline Keanggotaan & $\begin{array}{l}\text { Wilayah masyarakat dihuni oleh minimal } 4 \text { suku dan penerimaan suku baru harus di } \\
\text { bawah naungan } 4 \text { suku seperti yang terjadi di Koto Malintang, sedangkan di Simancuang, } \\
\text { penerimaan orang luar dilihat dari silsilah keluarga, biasanya lebih disukai berasal dari } \\
\text { Muaro Labuah dan sekitarnya. }\end{array}$ \\
\hline Hukum & $\begin{array}{l}\text { Adanya peradilan adat yang dikenal dengan rapek ampek jinih (rapat semua pihak) dan } \\
\text { rapek duo jinih (rapat panghulu/ niniak mamak dan wali nagari) seperti yang diterapkan } \\
\text { di Koto Malintang atau rapat perwakilan masyarakat seperti yang dilakukan di } \\
\text { Simancuang, penerapan sanksi adat, dan peraturan nagari. }\end{array}$ \\
\hline Reputasi & $\begin{array}{l}\text { Anak kemenakan mengikuti perintah mamak, mamak mengikuti perintah panghulu, } \\
\text { panghulu mengikuti kebenaran (kamanakan saparentah mamak, mamak nan saparentah } \\
\text { panghulu, panghulu saparentah bana). }\end{array}$ \\
\hline
\end{tabular}


(Axelrod, 1986) sebagaimana disajikan pada tabel 3. Proses-proses yang dapat mendukung norma terdiri atas meta norma (metanorms), dominansi, internalisasi, pencegahan, bukti sosial (social proof), keanggotaan, hukum, dan reputasi. Tabel 3 menguraikan lebih rinci bagaimana proses-proses tersebut berjalan pada masyarakat Koto Malintang dan Simancuang.

\section{Nilai}

Nilai-nilai masyarakat terhadap parak dan rimbo diuraikan dalam tabel 4. Konsep nilai tersebut dapat menggambarkan hal-hal yang penting menurut prinsip kelestarian, keadilan, kemampuan, keamanan, keuntungan, kesempatan, dan kesejahteraan. Informan menyampaikan bahwa keberadaan rimbo larangan, rimbo cadangan, dan parak adalah penting dalam ruang wilayah nagari bagi masyarakat Minangkabau sebagai entitas keberlanjutan masyarakat dan nagari. Parak dan rimbo terdistribusi menurut kaum dan suku dalam nagari atau diatur oleh nagari melalui kesepakatan pimpinan kaum dan suku. Berdasarkan pengamatan lapangan, pimpinan kaum dan suku memahami ruang dan kebutuhan dalam kaum dan sukunya. Pemahaman ini diinternalisasikan melalui keluarga, organisasi kaum, dan organisasi suku. Setiap keluarga, kaum, dan suku akan mempertahankan hak-hak ruang mereka sesuai dengan ketentuan adat dan hukum. Penggunaan ruang oleh keluarga, kaum, dan suku tetap mempertimbangkan efisiensi dalam konteks jarak, kebutuhan perlindungan, produktivitas, dan kebutuhan generasi mendatang. Meskipun demikian, pimpinan kaum dan suku juga memberikan kemudahan akses bagi anak kemenakan untuk memenuhi kebutuhannya. Oleh karena itu, setiap lahan budidaya harus diusahakan sebagaimana diperkuat dengan pernyataan informan sebagai berikut:

“...kalau di kampuang kami, kenyataannya, parak itu lebih malu kalau

Tabel 4

Nilai dalam Perencanaan, Pemanfaatan, dan Pengendalian Parak dan Rimbo

\begin{tabular}{|c|c|c|c|}
\hline Prinsip & Perencanaan & Pemanfaatan & Pengendalian \\
\hline Kelestarian & $\begin{array}{l}\text { Rimbo larangan, rimbo } \\
\text { cadangan, dan parak } \\
\text { sebagai entitas ruang } \\
\text { yang penting dalam } \\
\text { wilayah nagari }\end{array}$ & $\begin{array}{l}\text { Tidak berlebihan, ada yang } \\
\text { bisa dimanfaatkan untuk saat } \\
\text { ini dan ada yang } \\
\text { dimanfaatkan di masa yang } \\
\text { akan datang }\end{array}$ & $\begin{array}{l}\text { Tidak terjadi kerusakan tanah } \\
\text { dan air (dalam bentuk longsor } \\
\text { dan banjir) }\end{array}$ \\
\hline Keadilan & $\begin{array}{l}\text { Distribusi sumber daya } \\
\text { yang berkeadilan }\end{array}$ & $\begin{array}{l}\text { Hasil bersama diantara anak } \\
\text { kemenakan (periodisasi } \\
\text { pemanfaatan hasil) }\end{array}$ & $\begin{array}{l}\text { Tidak adanya ketimpangan } \\
\text { penguasaan sumber daya }\end{array}$ \\
\hline Kemampuan & $\begin{array}{l}\text { Pemahaman ruang dan } \\
\text { kebutuhan secara holistik }\end{array}$ & $\begin{array}{l}\text { Keterampilan mengolah lahan } \\
\text { dan budidaya pertanian }\end{array}$ & $\begin{array}{l}\text { Semua bentuk hasil parak dan } \\
\text { rimbo bermanfaat (termasuk } \\
\text { hasil ikutan) }\end{array}$ \\
\hline Keamanan & $\begin{array}{l}\text { Menjaga hak masing- } \\
\text { masing menurut adat dan } \\
\text { hukum }\end{array}$ & $\begin{array}{l}\text { Lahan dan hasilnya terjaga } \\
\text { dengan baik dari gangguan } \\
\text { (manusia dan hewan) }\end{array}$ & $\begin{array}{l}\text { Tidak ada perselisihan dalam } \\
\text { pengelolaan lahan }\end{array}$ \\
\hline Keuntungan & $\begin{array}{l}\text { Efisiensi penggunaan } \\
\text { sumber daya }\end{array}$ & $\begin{array}{l}\text { Tambahan pendapatan bagi } \\
\text { keluarga (inti dan } \\
\text { berkembang) }\end{array}$ & $\begin{array}{l}\text { Biaya operasional lebih mudah } \\
\text { dan murah }\end{array}$ \\
\hline Kesempatan & $\begin{array}{l}\text { Kemudahan akses } \\
\text { terhadap sumber daya }\end{array}$ & $\begin{array}{l}\text { Dukungan sarana dan } \\
\text { prasarana (produksi dan } \\
\text { pemasaran) }\end{array}$ & $\begin{array}{l}\text { Tersedianya akses sumber } \\
\text { daya dan operasional }\end{array}$ \\
\hline Kesejahteraan & $\begin{array}{l}\text { Pemenuhan kebutuhan } \\
\text { keluarga }\end{array}$ & $\begin{array}{l}\text { Manfaat ekonomi sumber } \\
\text { daya hutan (parak dan rimbo) }\end{array}$ & $\begin{array}{l}\text { Tidak adanya kemiskinan dan } \\
\text { pengangguran }\end{array}$ \\
\hline
\end{tabular}

Sumber: hasil wawancara dan pengamatan lapangan tahun 2015 sampai 2016 serta dikembangkan dari Rangkoto (1982) 
tidak ditanami, jadi otomatis harus diusahakan, sehingga kalau terjadi bencana, parak tersebut dapat menghadangnya"

Informan juga menyampaikan bahwa alokasi lahan yang seimbang diharapkan mengurangi perselisihan di antara anak kemenakan. Meskipun demikian, pemanfaatan lahan juga mempertimbangkan untung dan rugi. Biaya operasional yang murah dan mudah mendorong masyarakat untuk mengelola lahan secara intensif, apalagi kesempatan akses sumber daya dan operasional tersedia, terutama pasar. Dengan demikian, kemiskinan dan pengangguran menjadi hal yang seharusnya tidak terjadi pada anak kemenakan dalam nagari.

Nilai-nilai sebagaimana dijelaskan di atas dapat menjelaskan jenis-jenis motivasi menurut konsep Schwartz (1992) seperti disajikan pada tabel 5. Masyarakat Koto Malintang dan Simancuang mengembangkan nilai-nilai dengan motivasi kebebasan berpikir dan bertindak, stimulasi, hedonisme, prestasi, kekuasaan, keamanan, kepatutan, tradisi, spiritualitas, kebajikan, dan universalitas.

\section{Keyakinan}

Tabel 6 menyajikan keyakinan masyarakat dalam merencanakan, memanfaatkan, dan mengendalikan parak dan rimbo. Keyakinan tersebut dapat menggambarkan prinsip kelestarian, keadilan, kemampuan, keamanan, keuntungan, kesempatan, dan keamanan yang dianggap benar oleh masyarakat. Dalam perencanaan ruang kelola, masyarakat meyakini bahwa lahan lereng dapat digunakan untuk budidaya tanaman campuran (kayu, buahbuahan, dan pangan), sedangkan lahan datar

Tabel 5

Jenis-jenis Motivasi dari Nilai-nilai Masyarakat

\begin{tabular}{|c|c|}
\hline Jenis Motivasi & Uraian Nilai-nilai \\
\hline $\begin{array}{l}\text { Kebebasan berpikir } \\
\text { dan bertindak }\end{array}$ & $\begin{array}{l}\text { Adanya kebebasan untuk mengusahakan lahan parak dan rimbo berdasarkan } \\
\text { keputusan keluarga, kaum, dan suku yang tidak dapat diintervensi oleh yang lain }\end{array}$ \\
\hline Stimulasi & $\begin{array}{l}\text { Adanya keanekaragaman jenis tanaman dalam parak dan rimbo untuk memenuhi } \\
\text { ragam kebutuhan keluarga }\end{array}$ \\
\hline Hedonisme & $\begin{array}{l}\text { Adanya keinginan untuk memanfaatkan sumber daya parak dan rimbo untuk } \\
\text { kepentingan seluruh anak nagari }\end{array}$ \\
\hline Prestasi & $\begin{array}{l}\text { Adanya kesadaran tentang pentingnya keterampilan dalam budidaya dan } \\
\text { keberhasilan dalam mengelola lahan parak dan rimbo secara lestari }\end{array}$ \\
\hline Kekuasaan & Adanya pengakuan sosial dan kewenangan serta jaminan kesejahteraan \\
\hline Keamanan & $\begin{array}{l}\text { Adanya jaminan keamanan keluarga, kaum, dan suku dalam berusaha dan } \\
\text { mempertahankan tatanan sosial yang telah dibangun }\end{array}$ \\
\hline Kepatutan & $\begin{array}{l}\text { Adanya sikap menghargai pimpinan keluarga, kaum, suku, dan nagari serta } \\
\text { kesadaran menjaga perilaku bijak dalam mengelola lahan }\end{array}$ \\
\hline Tradisi & $\begin{array}{l}\text { Adanya pengakuan terhadap tradisi-tradisi dalam keluarga, kaum, dan suku, atau } \\
\text { nagari }\end{array}$ \\
\hline Spiritualitas & $\begin{array}{l}\text { Adanya kesadaran tentang pentingnya etika dan moral yang berlandaskan pada } \\
\text { agama (syariat Islam) }\end{array}$ \\
\hline Kebajikan & $\begin{array}{l}\text { Adanya sikap membantu, bertanggung jawab, dan persahabatan dalam keluarga, } \\
\text { kaum, suku, dan nagari }\end{array}$ \\
\hline Universalitas & $\begin{array}{l}\text { Adanya sikap yang menjamin kesetaraan, kesatuan dengan alam, perlindungan } \\
\text { alam, keadilan sosial, dan kearifan lokal }\end{array}$ \\
\hline
\end{tabular}


Tabel 6

Keyakinan dalam Perencanaan, Pemanfaatan, dan Pengendalian Parak dan Rimbo

\begin{tabular}{|c|c|c|c|}
\hline Prinsip & Perencanaan & Pemanfaatan & Pengendalian \\
\hline Kelestarian & $\begin{array}{l}\text { Lahan lereng dijadikan } \\
\text { parak, lahan datar untuk } \\
\text { sawah, dan daerah hulu } \\
\text { air sebagai rimbo } \\
\text { larangan }\end{array}$ & $\begin{array}{l}\text { Parak dan rimbo sebagai } \\
\text { cadangan penghasilan bagi } \\
\text { anak kemenakan (hiduik ka } \\
\text { tampek manumpang, salamat } \\
\text { barang palangkahan) }\end{array}$ & $\begin{array}{l}\text { Harta pusaka dapat diwariskan } \\
\text { turun-temurun (harato pusako } \\
\text { ndak habih, ingek sabalum } \\
\text { kanai) }\end{array}$ \\
\hline Keadilan & $\begin{array}{l}\text { Untuk anak kemenakan } \\
\text { (anak dipangku } \\
\text { kamanakan dibimbiang) }\end{array}$ & $\begin{array}{l}\text { Hak kelola milik perempuan, } \\
\text { hak kuasa milik laki-laki }\end{array}$ & $\begin{array}{l}\text { Harta anak kemenakan dapat } \\
\text { terpelihara }\end{array}$ \\
\hline Kemampuan & $\begin{array}{l}\text { Sesuai adat (adaik diisi, } \\
\text { limbago dituang) }\end{array}$ & $\begin{array}{l}\text { Sesuai dengan kebiasaan (baa } \\
\text { urang mode tu pulo kito) }\end{array}$ & $\begin{array}{l}\text { Jika orang mampu maka kita } \\
\text { juga mampu melakukannya }\end{array}$ \\
\hline Keamanan & $\begin{array}{l}\text { Tidak boleh merusak adat } \\
\text { (indak lakang dek paneh, } \\
\text { indak lapuak dek hujan) }\end{array}$ & $\begin{array}{l}\text { Mengolah sesuai dengan } \\
\text { pembagian (parak telah } \\
\text { dibagi-bagi dan rimbo yang } \\
\text { ada batasnya) }\end{array}$ & $\begin{array}{l}\text { Nagari harus aman dari } \\
\text { berbagai tindakan merusak }\end{array}$ \\
\hline Keuntungan & $\begin{array}{l}\text { Tidak menimbulkan } \\
\text { kerugian (awak mandapek } \\
\text { urang ndak kahilangan) }\end{array}$ & $\begin{array}{l}\text { Mendapatkan hasil sesuai } \\
\text { kerja (ka rimbo babungo } \\
\text { kayu, ka sawah babungo } \\
\text { ampiang) }\end{array}$ & $\begin{array}{l}\text { Ukurannya laba dan rugi dari } \\
\text { setiap usaha }\end{array}$ \\
\hline Kesempatan & $\begin{array}{l}\text { Mengikutsertakan seluruh } \\
\text { anak nagari (urang } \\
\text { kampuang samo } \\
\text { dipatenggangkan, } \\
\text { tenggang jo adat dan } \\
\text { pusaka) }\end{array}$ & $\begin{array}{l}\text { Pembagian hasil yang } \\
\text { mempertimbangkan } \\
\text { kebutuhan keluarga dan kaum } \\
\text { (anak kamanakan samo } \\
\text { dipatenggangkan) }\end{array}$ & $\begin{array}{l}\text { Akses sumber daya dan } \\
\text { pemasaran selalu ada }\end{array}$ \\
\hline Kesejahteraan & $\begin{array}{l}\text { Rajin berusaha akan } \\
\text { mendapatkan hasil yang } \\
\text { setimpal (nan mancacah } \\
\text { inyo nan dapek) }\end{array}$ & $\begin{array}{l}\text { Hasil yang melimpah } \\
\text { menjamin kehidupan } \\
\text { keluarga, kaum, suku, nagari }\end{array}$ & $\begin{array}{l}\text { Nagari maju dan berkembang } \\
\text { (batuah kampuang jo } \\
\text { halaman, bumi sanang, padi } \\
\text { manjadi) }\end{array}$ \\
\hline
\end{tabular}

Sumber: hasil wawancara dan pengamatan lapangan tahun 2015 sampai 2016 serta dikembangkan dari Rangkoto (1982)

dan berair lebih diarahkan sebagai sawah. Keyakinan ini dilukiskan dalam pepatah "nan lereng jadikan parak, nan bancah jadikan sawah, ka rimbo babungo kayu, ka sawah babungo ampiang (lahan lereng untuk parak, lahan datar untuk sawah, ke hutan menghasilkan kayu, ke sawah menghasilkan padi)". Sementara itu, hutan yang menjadi sumber air bagi sungai-sungai ditetapkan sebagai rimbo larangan. Ruang kelola yang telah diatur sejak dulu diwariskan turuntemurun kepada anak kemenakan secara berkeadilan. Oleh karena itu, anak kemenakan dituntut untuk menjalankan ruang kelola menurut adat dan cara yang telah diwariskan atau sering disebut dengan istilah "adaik diisi, limbago dituang (adat dipakai, lembaga dituang)". Anak kemenakan yang menerapkan adat dianggap benar karena adat hidup sepanjang masa sesuai dengan pepatah "indak lakang dek paneh, indak lapuak dek hujan (tidak rusak karena panas, tidak lapuk karena hujan)".

Pengaturan ruang kelola pada satu kaum atau suku tidak akan merugikan kaum atau suku lainnya. Jika satu keluarga mengelola suatu lahan, pengelolaan lahan tidak boleh mengganggu hak keluarga yang lain atau sering disebut dengan istilah "awak mandapek, urang ndak kahilangan (kita dapat tapi orang tidak kehilangan)". Sesuai dengan pengaturan ruang tersebut, semua anak kemenakan dalam nagari 
harus mendapatkan hak kelola dan menjadi penerima manfaat dari pengelolaan yang dilakukan. Menurut informan, hal tersebut melahirkan keyakinan bahwa setiap orang harus memiliki tenggang rasa sebagaimana disebut dengan istilah "urang kampuang samo dipatenggangkan, tenggang jo adaik dan pusako (semua orang kampung dipertimbangkan, ditimbang dengan adat dan pusaka)". Pengaturan ruang kelola yang demikian diharapkan menghasilkan kesejahteraan bagi keluarga, kaum, suku, dan nagari sesuai dengan kerja keras dari anak kemenakan yang disebut dengan istilah " $n a n$ mancacah inyo nan dapek (yang berusaha akan mendapatkan hasil)".

Parak dan rimbo diyakini sebagai sumber daya ekonomi alternatif selain sawah yang dapat menjadi sumber mata pencaharian anak kemenakan saat ini dan di masa yang akan datang. Informan menyampaikan bahwa hak kelola sumber daya ekonomi lebih dipercayakan kepada perempuan sesuai sistem matrilineal sebagaimana yang dianut oleh masyarakat Minangkabau pada umumnya, meskipun hak kuasa tetap berada pada laki-laki (panghulu dan niniak mamak). Pengelolaan parak dan rimbo berdasarkan kebiasaan yang sudah dilakukan sejak nenek moyang, meskipun ada perubahan komoditi yang dibudidayakan sesuai dengan permintaan pasar. Namun, tidak ada perubahan yang signifikan terhadap penggunaan lahan parak dan rimbo, kecuali untuk pemukiman. Lahan-lahan yang dimanfaatkan berdasarkan hak masing-masing sebagaimana disebut dengan istilah "sasuai warih nan bajawek, pusako nan ditarimo (sesuai dengan waris yang didapatkan dan pusaka yang diterima)". Pemanfaatan hasil sesuai dengan jenis-jenis tanaman yang dibudidayakan. Informan menyatakan bahwa, jika pada lahan tersebut sudah ada tanaman sebelumnya, maka hasil dari tanaman tersebut harus mempertimbangkan kebutuhan anggota keluarga dalam suatu keluarga atau kaum. Hal ini dapat dilihat dari pembagian hasil terhadap buah durian yang diatur pemanfaatan hasilnya bagi seluruh anggota keluarga. Pemanfaatan aneka ragam hasil parak dan rimbo diyakini akan memberikan kesejahteran bagi keluarga, kaum, suku, dan bahkan nagari.

Pengendalian parak dan rimbo dilakukan dengan mekanisme pewarisan harta pusaka secara turun-temurun, terutama harta pusaka tinggi. Informan menyatakan bahwa harta pusaka tidak akan pernah habis sebagaimana juga disebutkan dalam pantun adat Minangkabau (Rangkoto, 1982) sebagai berikut:

"Pusako tinggi tambilang basi, miliak kaum itu namonyo, walau pun kaum kambang di nagari, namun pusako tinggi baitu juo (harta pusaka tinggi seperti tembilang besi, merupakan milik kaum, meskipun anggota kaum bertambah banyak di nagari, namun harta tersebut akan seperti itu juga)"

Pimpinan adat (panghulu dan niniak mamak) harus mampu menjaga harta pusaka untuk keberlanjutan komunitas kaum dan sukunya sehingga anak kemenakan dapat terpelihara. Kewajiban panghulu dan niniak mamak terhadap harta pusaka tersebut dinyatakan dalam ketentuan adat (Hakimy, 1982) sebagai berikut:

"Kalau sumbiang dititiak, patah ditimpa, hilang dicari, tabanam disalami, anyuik dipinteh, talamun dikakeh, kurang ditukuak, rusak dibaiki (kalau sumbing harus dilengkapi, kalau patah harus disambung, kalau hilang harus dicari, kalau terbenam harus diangkat, kalau hanyut harus ditolong, kalau termenung harus diingatkan, kalau kurang harus ditambah, kalau rusak harus diperbaiki)"

Informan selanjutnya juga menyatakan bahwa mereka mampu menjaga waris dan pusaka sebagaimana nenek moyang atau masyarakat lain mampu menjaganya. Oleh karena itu, tindakan merusak terhadap parak dan rimbo juga dinilai sebagai tindakan merusak waris dan pusaka, bahkan dinilai telah melanggar adat. Mereka juga meyakini bahwa setiap usaha dari waris yang didapatkan dan pusaka yang diterima akan mendapatkan hasil 
yang menguntungkan secara finansial. Keyakinan tersebut diperkuat dengan kesempatan akses sumber daya yang memadai dan sesuai kebutuhan pasar. Jika semua hal yang diyakini tersebut berjalan, perkembangan nagari akan lebih maju yang sering disebut dengan istilah "kok dapek anak undamundaman, pamenan patang jo pagi, batuah kampuang jo halaman, bumi sanang padi manjadi (kalau dapat anak yang baik, pelipur lara di hari petang dan pagi, bertuah kampung dan halaman, bumi senang, padi menjadi)".

\section{Sikap}

Sikap masyarakat dalam pengelolaan parak dan rimbo diuraikan pada tabel 7. Sikap dapat dikategorikan menurut prinsip kelestarian, keadilan, kemampuan, keamanan, keuntungan, kesempatan, dan keamanan. Informan menyatakan bahwa meskipun dalam pengaturannya mengutamakan anak kemenakan, pembagiannya juga berdasarkan kepantasan dan kepatutan. Oleh karena itu, panghulu atau niniak mamak akan selalu menjaga parak dan rimbo sebagai pusaka sebagaimana disebut dengan istilah "dari niniak turun ka mamak, dari mamak turun ka kamanakan (dari niniak diwariskan ke mamak, dari mamak diwariskan ke anak kemenakan)".

Informan juga menyatakan bahwa mereka meyakini aksi yang dilakukan oleh anggota masyarakat yang lain berdasarkan hasil dari tanaman yang dibudidayakan. Nilai dan keyakinan merasionalisasi sikap untuk memberikan kesempatan kepada anggota masyarakat lainnya untuk mengelola lahan

Tabel 7

Sikap dalam Perencanaan, Pemanfaatan, dan Pengendalian Parak dan Rimbo

\begin{tabular}{|c|c|c|c|}
\hline Prinsip & Perencanaan & Pemanfaatan & Pengendalian \\
\hline Kelestarian & $\begin{array}{l}\text { Parak dan rimbo harus } \\
\text { ada dalam tata ruang } \\
\text { nagari }\end{array}$ & $\begin{array}{l}\text { Sesuai peruntukan, tahu mana } \\
\text { yang bisa dimanfaatkan dan } \\
\text { mana yang tidak }\end{array}$ & $\begin{array}{l}\text { Melihat fenomena dan gejala } \\
\text { alam/ bencana alam, terutama } \\
\text { banjir dan longsor }\end{array}$ \\
\hline Keadilan & $\begin{array}{l}\text { Pembagian sumber daya } \\
\text { menurut ketentuan (alua } \\
\text { jo patuik) }\end{array}$ & $\begin{array}{l}\text { Diusahakan langsung oleh } \\
\text { anak kemenakan atau } \\
\text { memiliki hubungan keluarga }\end{array}$ & $\begin{array}{l}\text { Ketimpangan antara yang kaya } \\
\text { dan miskin tidak kentara }\end{array}$ \\
\hline Kemampuan & $\begin{array}{l}\text { Mengutamakan anak } \\
\text { kemenakan dalam } \\
\text { mengelola lahan }\end{array}$ & $\begin{array}{l}\text { Harus ada kemauan dan } \\
\text { kesempatan (aturan latak) }\end{array}$ & $\begin{array}{l}\text { Saling membantu yang lain } \\
\text { (dalam bentuk modal } \\
\text { finansial, tenaga, dan } \\
\text { pengetahuan) }\end{array}$ \\
\hline Keamanan & $\begin{array}{l}\text { Menjaga harta pusaka } \\
\text { (dari niniak turun ka } \\
\text { mamak, dari mamak ka } \\
\text { kamanakan) }\end{array}$ & $\begin{array}{l}\text { Bekerja baik, menjaga } \\
\text { kampung dan nagari (aman } \\
\text { kampuang dek karajo elok) }\end{array}$ & $\begin{array}{l}\text { Saling menjaga (elok nagari } \\
\text { dek panghulu, rancak tapian } \\
\text { dek rang mudo, baiaknyo } \\
\text { kampuang di rang tuo) }\end{array}$ \\
\hline Keuntungan & $\begin{array}{l}\text { Mengusahakan budidaya } \\
\text { yang menguntungkan } \\
\text { (karajo tu yo nan ka } \\
\text { manguntuangkan) }\end{array}$ & $\begin{array}{l}\text { Memelihara usaha (seperti } \\
\text { tanaman, hasil panen, dan } \\
\text { usaha lain) yang } \\
\text { menguntungkan }\end{array}$ & $\begin{array}{l}\text { Ragam usaha, tidak } \\
\text { mengandalkan satu sumber } \\
\text { mata pencaharian }\end{array}$ \\
\hline Kesempatan & $\begin{array}{l}\text { Memberikan peluang } \\
\text { kepada anak kemenakan } \\
\text { (tenggang raso jo pareso) }\end{array}$ & $\begin{array}{l}\text { Sesuai dengan waris yang } \\
\text { diterima dan harta yang } \\
\text { ditinggalkan (warih nan } \\
\text { bajawek pusako nan } \\
\text { batinggakan) }\end{array}$ & $\begin{array}{l}\text { Mendapat persetujuan } \\
\text { keluarga, niniak mamak, dan } \\
\text { pemerintah }\end{array}$ \\
\hline Kesejahteraan & $\begin{array}{l}\text { Peningkatan } \\
\text { pendapatan/penghasilan } \\
\text { sebagai ukuran }\end{array}$ & $\begin{array}{l}\text { Setiap harta pusaka } \\
\text { memberikan manfaat } \\
\text { ekonomi bagi keluarga, kaum, } \\
\text { suku, nagari }\end{array}$ & $\begin{array}{l}\text { Dinikmati oleh seluruh anak } \\
\text { nagari }\end{array}$ \\
\hline
\end{tabular}


dalam rangka peningkatan kesejahteraan.

Pemanfaatan parak dan rimbo dilakukan sesuai dengan peruntukan yang telah diatur dalam ketentuan adat. Informan menyampaikan bahwa masyarakat tidak berani mengolah lahan yang dilarang dalam ketentuan adat dan akan mengolah lahan bila sudah mendapatkan izin dari pimpinan kaum atau suku (panghulu atau niniak mamak). Pemanfaatan lahan juga langsung dilakukan oleh anak kemenakan yang berhak atau memiliki hubungan keluarga sesuai silsilah dalam keluarga, kaum, atau suku. Lahan tidak mungkin dikelola oleh orang yang tidak memiliki hubungan keluarga. Anak kemenakan yang dapat mengolah lahan diukur menurut kemauan dan kemampuan, bahkan informan juga menyampaikan bahwa lahan yang tidak dikelola akan dikembalikan kepada kaum atau suku. Oleh karena itu, anak kemenakan diminta untuk mengolah lahan dengan baik, menjaga "adaik salingka nagari (adat selingkar nagari)", dan memelihara lahan dengan segala tanamannya sebagai sumber penghidupan keluarga.

Informan menyampaikan bahwa niniak mamak sering menyampaikan pentingnya parak dan rimbo dalam konteks bahaya banjir dan longsor. Oleh karena itu, banjir dan longsor memang menjadi kejadian-kejadian bencana alam yang selalu mengkhawatirkan bagi masyarakat Minangkabau yang tinggal sepanjang Bukit Barisan.

\section{Diskusi}

\section{Norma}

Masyarakat mengkonstruksikan norma sosial secara bersama berdasarkan pengalaman mereka terhadap suatu situasi (Valsiner, 2003). Norma sosial dapat berupa aturan dan standar yang dipahami oleh anggota masyarakat sebagai panduan perilaku sosial (Cialdini \& Trost, 1998). Anggota masyarakat harus mengikuti tindakan dalam cara tertentu dan dapat dikenakan sanksi bila melakukan tindakan dalam cara yang lain (Axelrod, 1986; Kandori, 1992; Ruff dkk., 2013; Mackie dkk.,
2014) sebagai bentuk pengakuan terhadap norma yang berlaku.

Parak dan rimbo dapat menjadi harta pusaka tinggi dan harta pusaka rendah (von Benda-Beckmann \& von Benda-Beckmann, 2012; von Benda-Beckmann, 2013; Stark, 2014; bin Haron \& Hanifuddin, 2018). Bagi masyarakat Koto Malintang, seluruh parak dan rimbo merupakan harta pusaka tinggi, sedangkan bagi masyarakat Simancuang, ada parak dan rimbo yang kemudian merupakan harta pusaka rendah. Namun demikian, parak dan rimbo bukanlah barang komoditas yang dengan mudah diperjualbelikan.

Pemanfaatan parak dan rimbo dilakukan menurut fungsinya yang turun-temurun dipahami masyarakat. Berdasarkan pengamatan lapangan, hutan belantara yang merupakan hulu bagi sungai-sungai dipertahankan menjadi hutan larangan (rimbo larangan), sedangkan hutan yang belum diolah merupakan hutan cadangan bagi perluasan lahan pertanian dan pemukiman atau sering disebut dengan rimbo cadangan. Hutan yang telah diolah menjadi lahan pertanian dan perkebunan campuran disebut dengan parak yang berfungsi produksi dan perlindungan. Pemahaman ini menjadi lazim ditemui pada masyarakat Minangkabau di Sumatera Barat (Martial dkk., 2012; Nursidah dkk., 2012; Hamzah dkk., 2015), termasuk bagi masyarakat Koto Malintang dan Simancuang.

Campuran tanaman merupakan suatu strategi mempertahankan sumber-sumber mata pencaharian (Otsuka, 2009; Webb, 2017; Octavia \& Rachmat, 2020) dan mengamankan wilayah pemukiman dari bencana alam (terutama banjir dan longsor). Parak menjadi sumber pendapatan bagi keluarga dan memperkuat sistem kekeluargaan dalam kaum dan suku. Oleh karena itu, pemanfaatan hasil parak juga tidak hanya bersifat individu, namun juga ada aturan manfaat bersama. Dalam kasus masyarakat Koto Malintang dan Simancuang, buah durian menjadi hasil parak yang dapat dimanfaatkan oleh setiap anggota masyarakat sesuai dengan aturan yang telah dipahami. 
Areal kelola parak dan rimbo harus dapat dikelola oleh anak kemenakan dari generasi ke generasi. Hak kelola tersebut diatur secara adil oleh panghulu dan niniak mamak. Pengaturan juga mempertimbangkan kondisi yang akan datang. Oleh karena itu, lahan-lahan yang menjadi hak anak kemenakan harus dapat dijaga dan selalu dimanfaatkan oleh anak kemenakan. Lahan-lahan yang terlantar dapat dipertimbangkan oleh panghulu dan niniak mamak untuk dikelola oleh anak kemenakan yang membutuhkan. Batas areal kelola masingmasing anak kemenakan menunjukkan wilayah kelola kaum dan suku yang ada. Dalam pantun masyarakat, kita sering mendengar istilah "rimbo nan bajariang, parak nan babintalak, sawah nan bapamatang (rimbo yang memiliki tanda, parak yang memiliki batas, dan sawah yang memiliki pematang)" sebagaimana juga sering diungkapkan oleh informan. Anak kemenakan dari kaum dan suku yang satu tidak boleh melanggar batas kelola kaum dan suku yang lain. Dengan demikian, pengelolaan lahan yang ada mampu menjamin kebutuhan ekonomi anak kemenakan dari keluarga, kaum, dan suku yang berhak.

Mekanisme untuk mendukung norma dielaborasi lebih mendalam menurut konsep (Axelrod, 1986). Proses-proses yang dapat mendukung norma terdiri atas meta norma (metanorms), dominansi, internalisasi, pencegahan, bukti sosial (social proof), keanggotaan, hukum, dan reputasi. Norma yang dimiliki masyarakat Koto Malintang dan Simancuang dalam mengelola sumber daya alam dan lingkungannya dapat berjalan stabil melalui sistem sosial yang dikembangkan oleh masyarakat itu sendiri. Oleh karena itu, setiap intervensi luar yang mengubah sistem sosial dapat mengubah norma masyarakat. Hal ini selalu menjadi tantangan bagi masyarakat lokal maupun masyarakat hukum adat yang dituntut untuk memenuhi kebutuhan pembangunan daerah dan nasional.

\section{Nilai}

Pemahaman terhadap keinginan individu atau kelompok dan ukuran kesejahteraannya dapat menjadi titik awal untuk memahami nilainilai (Schumpeter, 1909; Mulyana dkk., 2019; Fahmi dkk., 2019). Individu atau kelompok mengkonseptualisasikan nilai-nilai dengan penekanan pada standar dan ideal yang merepresentasikan apakah mereka percaya sesuatu terjadi atau ingin sesuatu terjadi (Karney dkk., 2003; Tsirogianni \& Gaskell, 2011). Secara komprehensif, Schwartz (1992) dan Schwartz (2012) telah merumuskan bahwa nilai-nilai dapat berupa konsep atau keyakinan, berhubungan dengan keadaan akhir atau perilaku yang diinginkan, melampaui situasi tertentu, memandu pemilihan atau evaluasi perilaku dan kejadian, serta disusun berdasarkan kepentingan relatif.

Nilai-nilai masyarakat terhadap parak dan rimbo menggambarkan hal-hal yang penting menurut prinsip kelestarian, keadilan, kemampuan, keamanan, keuntungan, kesempatan, dan kesejahteraan. Oleh karena itu, parak dan rimbo merupakan sumber daya yang penting dalam pemenuhan kebutuhan keluarga menuju kesejahteraan. Pemanfaatan parak dan rimbo dilakukan secara tidak berlebihan. Masyarakat mengatur lahan-lahan yang boleh dimanfaatkan saat ini dan yang perlu dicadangkan untuk generasi mendatang. Pengaturan bagi manfaat juga dilakukan, baik untuk kepentingan individu maupun untuk kepentingan bersama. Anak kemenakan yang mengelola lahan parak dituntut untuk memiliki keterampilan budidaya pertanian dan menjaga lahan dari gangguan manusia dan hewan.

Pengelolaan parak dan rimbo merupakan sumber mata pencaharian alternatif untuk tambahan pendapatan keluarga selain sawah. Pemanfaatan lahan juga bergantung pada dukungan sarana dan prasarana, terutama produksi dan pemasaran. Berdasarkan wawancara dan pengamatan lapangan, banyak infrastruktur produksi dan pasar dibuat secara swadaya oleh masyarakat karena pertimbangan manfaat ekonomi dari parak dan rimbo yang menjadi tolok ukur bagi masyarakat dalam pemanfaatan. Pengendalian parak dan rimbo diukur dari ada atau tidak adanya kerusakan 
yang menyebabkan bencana alam seperti banjir dan longsor. Kejadian longsor dan banjir memang menjadi perhatian bagi masyarakat lokal yang menempati wilayah perbukitan seperti di Sumatera Barat, terutama pada saat musim hujan dan cuaca ekstrim (BPBD Sumbar, 2015; (Fransiska dkk., 2017). Masyarakat Koto Malintang dan Simancuang sangat menyadari potensi bencana tersebut. Sementara itu, penguasaan lahan diantara masyarakat juga harus seimbang, baik dalam keluarga, kaum, maupun suku. Lahan dinilai sebagai sumber daya ekonomi untuk memenuhi kebutuhan masyarakat, sehingga setiap hasil usaha dari lahan yang ada harus dapat dimanfaatkan.

Nilai-nilai sebagaimana dijelaskan di atas dapat menjelaskan jenis-jenis motivasi menurut konsep Schwartz (1992). Masyarakat Koto Malintang dan Simancuang mengembangkan nilai-nilai dengan motivasi kebebasan berpikir dan bertindak, stimulasi, hedonisme, prestasi, kekuasaan, keamanan, kepatutan, tradisi, spiritualitas, kebajikan, dan universalitas. Motivasi tersebut dapat dinilai sebagai tujuan masyarakat mengelola lahan dan mempertahankan praktik-praktik kelola yang telah berkembang dari generasi ke generasi. Bahkan, motivasi tersebut dapat juga dinilai sebagai argumentasi-argumentasi masyarakat tentang pentingnya parak dan rimbo bagi komunitas mereka. Setiap keputusan dan tindakan masyarakat akan selalu berlandaskan nilai-nilai yang mereka akui.

\section{Keyakinan}

Pengelolaan sumber daya alam dan lingkungan, termasuk hutan, juga berdasarkan keyakinan yang berkembang dalam suatu komunitas. Keyakinan memang merupakan sebuah representasi yang abstrak (Robinson \& Clore, 2002; Usó-Doménech dkk., 2015), namun demikian, keyakinan dapat dinilai sebagai ide, teori, dan asumsi umum atau juga dapat menunjukkan sebuah ekspektasi tertentu (Karney dkk., 2003; Nescolarde-Selva dkk., 2017). Sistem keyakinan berdasarkan pada komponen evaluatif dan afektif yang merasionalisasi pada apa yang baik dan apa yang buruk (Usó-Doménech \& NescolardeSelva, 2016).

Keyakinan masyarakat tertanam dalam merencanakan, memanfaatkan, dan mengendalikan parak dan rimbo. Keyakinan tersebut dapat menggambarkan prinsip kelestarian, keadilan, kemampuan, keamanan, keuntungan, kesempatan, dan keamanan yang dianggap benar oleh masyarakat.

Pemahaman terhadap keyakinan masyarakat Minangkabau memang dapat dilakukan dengan mempelajari pantun adat dan tradisi budaya yang masih melekat. Masyarakat Koto Malintang dan Simancuang merupakan bagian masyarakat Minangkabau yang masih menerapkan tradisi-tradisi budaya Minangkabau dan menyebarluaskan keyakinan melalui pantun. Eksistensi pantun adat yang masih kuat mendorong internalisasi keyakinan kepada anak kemenakan. Pantun adat selalu disampaikan pada pertemuan-pertemuan kaum atau suku dan upacara-upacara adat. Bahkan, nasihat orang tua kepada anak dalam suatu keluarga juga sering menggunakan pantun adat yang disampaikan secara turun-temurun.

\section{Sikap}

Respon masyarakat terhadap seseorang, objek, perilaku, atau kebijakan melahirkan sikap (Ajzen \& Fishbein, 1977; Sweetman dkk., 2019). Sikap memiliki hubungan dengan perilaku yang menunjukkan perasaan evaluatif dalam bentuk suka atau tidak suka terhadap sesuatu (Wicker, 1969; Chaiklin, 2011). Respon atau perasaan yang ditunjukkan mempertimbangkan nilai dan keyakinan yang dimiliki oleh individu atau kelompok. Sikap masyarakat dalam pengelolaan parak dan rimbo dapat dikategorikan menurut prinsip kelestarian, keadilan, kemampuan, keamanan, keuntungan, kesempatan, dan keamanan. Bagi masyarakat, parak dan rimbo adalah entitas penting dalam mendukung keberlanjutan komunitas mereka. Hal ini sesuai dengan penjelasan von BendaBeckmann (2013) bahwa semua rimbo adalah tanah raja, sedangkan rimbo yang dapat diolah (rimbo cadangan) adalah milik kepala suku/ kaum (panghulu/ niniak mamak) dan rimbo 
yang telah diolah (parak dan sawah) adalah milik anak kemenakan. Parak dan rimbo diatur menurut filosofi "alua jo patuik" (kepantasan dan kepatutan).

Masyarakat membudidayakan jenis-jenis tanaman yang menguntungkan secara ekonomi berdasarkan nilai dan keyakinan yang diakuinya. Informan menyampaikan bahwa pertimbangan untung rugi juga menjadi dasar penentuan jenis tanaman selain dari pertimbangan sosial dan ekologi. Bagi masyarakat Minangkabau pada umumnya, kekuatan sistem sosio-ekonomis dan pengaturan sosioekologis yang telah berkembang sejak dulunya memberikan kemantapan bersikap untuk menentukan jenisjenis tanaman yang dibudidayakan (Oki, 1984; David \& Ploeger, 2014; Asrina dkk., 2017). Berdasarkan pengamatan lapangan, pilihan jenis tanaman relatif hampir sama antar anggota masyarakat sehingga bentang lahan (landscape) dan keanekaragaman parak relatif sama juga.

Sikap masyarakat dalam pengendalian parak dan rimbo memang diukur dari kejadian bencana alam akibat kesalahan dalam mengelola lahan. Kejadian banjir dan longsor menjadi indikator bahwa anak kemenakan perlu memperbaiki cara pengelolaan lahan. Hal ini disebarluaskan kepada anak kemenakan sebagaimana pantun adat (Rangkoto, 1982): "Manuruik sapanjang alua, manampuah sapanjang jalan, agaklah langkah kok talanjua, kudian kok jadi sasalan (mengikuti menurut alur, menempuh menurut jalan, pertimbangkan langkah yang terlanjur, di kemudian hari bisa menjadi penyesalan)". Kejadian banjir dan longsor merupakan kejadian bencana alam paling banyak terjadi di Sumatera Barat (Bapedalda Sumbar, 2015; Rozi, 2017; Tasri dkk., 2020), terutama pada wilayah-wilayah perbukitan seperti di Koto Malintang dan Simancuang.

Parak dan rimbo juga menjadi sumber daya ekonomi yang digunakan untuk memberikan kesempatan berusaha kepada anak kemenakan. Ketimpangan ekonomi dalam kaum atau suku dan nagari harus dihindari sehingga sikap saling membantu antar keluarga dan saling menjaga parak dan rimbo sebagai sumber daya nagari menjadi sebuah kewajiban. Hal ini direpresentasikan dalam pepatah "elok nagari dek panghulu, rancak tapian dek rang mudo, baiaknyo kampuang di rang tuo (majunya nagari oleh panghulu, indahnya tepian oleh anak kemenakan, baiknya kampung oleh orang tua)". Oleh karena itu, untuk mempertahankan sumber penghidupannya, masyarakat memilih untuk membudidayakan aneka jenis tanaman dan aneka usaha yang mendatangkan manfaat ekonomi bagi keluarga. Sikap ini juga tidak dapat dilepaskan dari keputusan keluarga, kaum, atau suku yang merasionalisasi pilihan-pilihan usaha individu, selain dari pengaruh pasar. Contohnya, pohon durian menjadi salah satu jenis tanaman yang terus dibudidayakan dan dipelihara masyarakat Koto Malintang sebagai pohon milik bersama.

\section{Implikasi bagi Kebijakan Pengelolaan Hutan}

Modal sosial kognitif memberikan landasan instrumental bagi desain peran, aturan, prosedur, preseden, dan jejaring yang dikembangkan oleh masyarakat sekitar hutan dalam pengelolaan sumber daya hutan. Seperangkat norma dan nilai dapat dibangkitkan dari pengetahuan masyarakat lokal yang dibagikan secara turun-temurun (Jaenudin \& Tahrir, 2019). Norma dan nilai yang berkembang memberikan gambaran keyakinan dan sikap masyarakat dalam pengelolaan sumber daya hutan.

Pengakuan terhadap norma, nilai, keyakinan, dan sikap masyarakat adalah penting untuk mewujudkan pengelolaan hutan lestari. Praktik parak yang telah berkembang perlu mendapatkan dukungan dalam kebijakan pengelolaan hutan (Martial, 2011) karena banyak penelitian telah membuktikan bahwa parak mampu menyediakan biodiversitas (Santhyami dkk., 2018; Sumilia dkk., 2019) dan memberikan manfaat sosial ekonomi yang memperkuat sistem sosial masyarakat sekitar hutan (Villamor dkk., 2015). Praktik rimbo dalam tata ruang wilayah nagari (desa) juga terbukti memperkuat sistem pengelolaan lahan yang memberikan peluang bagi masyarakat 
untuk mempertahankan sumber-sumber mata pencahariannya (Asmin, 2015; Tanjung dkk., 2017; Wulandari dkk., 2018).

Parak dan rimbo dilandasi oleh norma, nilai, keyakinan, dan sikap masyarakat dalam pengelolaan sumber daya hutan. Oleh karena itu, peneliti modal sosial perlu menggali lebih dalam elemen-elemen kognitif dari modal sosial tersebut untuk dapat menggambarkan praktikpraktik kelola sumber daya alam berbasis masyarakat kepada pengambil kebijakan. Dengan demikian, kajian modal sosial kognitif dapat menjadi landasan implementatif bagi kebijakan pengelolaan hutan di tingkat nasional dan daerah.

\section{Simpulan}

Modal sosial kognitif berupa norma, nilai, keyakinan, dan sikap dapat teridentifikasi dari praktik kelola parak dan rimbo. Sebagai sebuah praktik berbasis pengetahuan ekologis lokal, elemen-elemen kognitif dari modal sosial tersebut memberikan gambaran bagaimana masyarakat merencanakan, memanfaatkan, dan mengendalikan pengelolaan sumber daya hutan. Adat dan budaya Minangkabau menjadi landasan kognitif bagi kekuatan modal sosial kognitif untuk mengelola sumber daya hutan dengan memperhatikan prinsip kelestarian, keadilan, kemampuan, keamanan, keuntungan, kesempatan, dan kesejahteraan. Dengan mengelaborasi elemen-elemen kognitif dari modal sosial secara komprehensif, peneliti modal sosial dimungkinkan untuk mempertimbangkan aspek sistem dalam pengukuran modal sosial, terutama untuk menggambarkan modal sosial struktural secara cermat.

\section{Referensi}

Adom, D., Yeboah, A., \& Ankrah, A. K. (2016). Constructivism philosophical paradigm: Implication for research, teaching and learning. Global Journal of Arts Humanities and Social Sciences, 4(10), 1-9.
Ajzen, I., \& Fishbein, M. (1977). Attitudebehavior relations: A theoretical analysis and review of empirical research. Psychological Bulletin, 84(5), 888-918. https://doi.org/10.1037/00332909.84.5.888

Amineh, R. J., \& Asl, H. D. (2015). Review of constructivism and social constructivism. Journal of Social Sciences, Literature and Languages, 1(1), 9-16.

Ansari, S., Munir, K., \& Gregg, T. (2012). Impact at the 'bottom of the pyramid': The role of social capital in capability development and community empowerment. Journal of Management Studies, $\quad 49(4), \quad 813-842$. https://doi.org/10.1111/j.14676486.2012.01042.x

Asmin, F. (2015). Pengelolaan hutan nagari di Sumatera Barat: Studi kasus areal kelola hutan nagari di Jorong Simancuang Provinsi Sumatera Barat. Prosiding Seminar Nasional FMIPA Universitas Terbuka, 89-112. https://doi.org/10.15294/komunitas.v8i2.58 56

Asmin, F. (2018). Konstruksi modal sosial bagi pengelolaan hutan berbasis masyarakat: Sebuah kerangka konseptual. Jurnal Ilmu Sosial dan Humaniora, 7(1), 32-45. https://doi.org/http://dx.doi.org/10.23887/ji sh-undiksha.v7i1.13301

Asmin, F., Darusman, D., Ichwandi, I., \& Suharjito, D. (2016). Local ecological knowledge on forest clearing: A case study of parak and rimbo practices in Simancuang Community, Indonesia. Komunitas: International Journal of Indonesian Society and Culture, 8(2), 208220.

https://doi.org/10.15294/komunitas.v8i2.58 56

Asmin, F., Darusman, D., Ichwandi, I., \& Suharjito, D. (2017). Elaborating the attributes of local ecological knowledge: A case study of parak and rimbo practices in Koto Malintang Village. Advanced Science 
Letters, 23(4), 2812-2817. https://doi.org/10.1166/asl.2017.7682

Asrina, M., Gunawan, A., \& Aris, M. (2017). Identification of Minangkabau landscape characters. IOP Conference Series: Earth and Environmental Science, 91(1), 12-18. https://doi.org/10.1088/17551315/91/1/012018

Axelrod, R. (1986). An evolutionary approach to norms. The American Political Science Review, $\quad$ 80(4), 1095-1111. https://doi.org/10.1017/S00030554001850 16

Bapedalda Sumbar. (2015). Buku Data Status Lingkungan Hidup Daerah Tahun 2014. Badan Pengendalian Lingkungan Hidup Daerah Provinsi Sumatera Barat.

bin Haron, M. S., \& Hanifuddin, I. (2018). Harta dalam konsepsi adat Minangkabau. JURIS (Jurnal Ilmiah Syariah), 11(1), 113. https://doi.org/10.1234/juris.v11i1.947

Borg, R., Toikka, A., \& Primmer, E. (2015). Social capital and governance: A social network analysis of forest biodiversity collaboration in Central Finland. Forest Policy and Economics, 50, 90-97. https://doi.org/10.1016/j.forpol.2014.06.00 8

BPBD Sumbar. (2015). Laporan tahunan PUSDALOPS PB badan penanggulangan bencana daerah (BPBD) Provinsi Sumatera Barat 2015. Badan Penanggulangan Bencana Daerah Provinsi Sumatera Barat.

Bussey, J., Davenport, M. A., Emery, M. R., \& Carroll, C. (2016). "A lot of it comes from the heart": The nature and integration of ecological knowledge in tribal and nontribal forest management. Journal of Forestry, 114(2), 97-107. http://dx.doi.org/10.5849/jof.14-130

Castiglione, D. (2008). Introduction: Conceptual issues in social capital theory. Dalam D. Castiglione, J. van Deth, \& G. Wolleb (Eds.), The handbook of social capital (hal. 13-21). Oxford University Press.
Chaiklin, H. (2011). Attitudes, behavior, and social practice. Journal of Sociology \& Social Welfare, 38(1), 31-54.

Chambers, R. (1995). Poverty and livelihoods: Whose reality counts? Environment and Urbanization, 7(1), 173-204. https://doi.org/10.1177/095624789500700 106

Chambers, R., \& Conway, G. (1992). Sustainable rural livelihoods: Practical concepts for the 21st century (No. 296). Institute of Development Studies (UK).

Charnley, S., Fischer, A., \& Jones, E. (2008). Traditional and local ecological knowledge about forest biodiversity in the Pacific Northwest. U.S. Department of Agriculture.

Chaskin, R., Goerge, R., Skyles, A., \& Guiltinan, S. (2006). Measuring social capital: An exploration in communityresearch partnership. Journal of Community Psychology, 34(4), 489-514. https://doi.org/10.1002/jcop.20111

Cialdini, R. B., \& Trost, M. R. (1998). Social influence: Social norms, conformity and compliance. Dalam D. T. Gilbert, S. T. Fiske, \& G. Lindzey (Eds.), The handbook of social psychology (hal. 151-192). McGraw-Hill.

David, W., \& Ploeger, A. (2014). Indigenous knowledge (IK) of water resources management in West Sumatera, Indonesia. Future of Food: Journal on Food, Agriculture and Society, 2(1), 40-44.

Ekawati, S., \& Nurrochmat, D. (2014). Hubungan modal sosial dengan pemanfaatan dan kelestarian hutan lindung. Jurnal Analisis Kebijakan Kehutanan, $\quad$ 11(1), 40-53. https://doi.org/10.20886/jakk.2014.11.1.40 $-53$

Eric, E. (2019). Hubungan antara hukum Islam dan hukum adat dalam pembagian warisan di dalam masyarakat Minangkabau. Jurnal Muara Ilmu Sosial, Humaniora, dan Seni, 3(1), 61-70. https://doi.org/10.24912/ jmishumsen.v3i1.3532 
Esser, H. (2008). The two meaning of social capital. Dalam D. Castiglione, J. van Deth, \& G. Wolleb (Eds.), The handbook of social capital (hal. 22-49). Oxford University Press.

Fahmi, I., Takwin, B., \& Muhamad, R. (2019). Nilai moral sebagai prediktor orientasi politik pada anggota organisasi keagamaan. Psympathic: Jurnal Ilmiah Psikologi, 6(2), 165-180. https://doi.org/10.15575/psy.v6i2.6260

Felício, J. A., Couto, E., \& Caiado, J. (2014). Human capital, social capital and organizational performance. Management Decision, 52(2), 350-364. https://doi.org/10.1108/md-04-2013-0260

Firdaus, D. R. S. (2019). The coexistence between matrilineal family structures and the religious order of the Minangkabau community. Jurnal Komunikasi Ikatan Sarjana Komunikasi Indonesia, 4(1), 18 25.

https://doi.org/10.25008/jkiski.v4i1.223

Forrest, R., \& Kearns, A. (2001). Social cohesion, social capital and the neighbourhood. Urban Studies, 38(12), 2125-2143.

https://doi.org/10.1080/004209801200870 81

Fransiska, L., Tjahjono, B., \& Gandasasmita, K. (2017). Studi geomorfologi dan analisis bahaya longsor di Kabupaten Agam, Sumatera Barat. Buletin Tanah dan Lahan, 1(1), 51-57.

García-Amado, L. R., Pérez, M. R., IniestaArandia, I., Dahringer, G., Reyes, F., \& Barrasa, S. (2012). Building ties: Social capital network analysis of a forest community in a biosphere reserve in Chiapas, Mexico. Ecology and Society, 17(3), 1-12. https://doi.org/http://dx.doi.org/10.5751/ES $-04855-170303$

Gibson, C., Williams, J., \& Ostrom, E. (1999). Social capital and the governance of forest resources. Workshop in Political Theory and Policy Analysis, 12. Indiana
University.

http://dlc.dlib.indiana.edu/dlc/handle/1053 $5 / 4454$

Gorriz-Mifsud, E., Secco, L., Da Re, R., Pisani, E., \& Bonet, J. A. (2017). Structural social capital and local-level forest governance: Do they inter-relate? A mushroom permit case in Catalonia. Journal of Environmental Management, 188, 364378.

http://dx.doi.org/10.1016/j.jenvman.2016.1 1.072

Guba, E. G., \& Lincoln, Y. S. (1994). Competing paradigms in qualitative research. Dalam N. Denzin \& Y. Lincoln (Eds.), Handbook of qualitative research (hal. 105-117). Sage.

Hakimy, I. (1982). Pegangan penghulu di Minangkabau. PN Balai Pustaka.

Hamzah, Suharjito, D., \& Istomo. (2015). Efektifitas kelembagaan lokal dalam pengelolaan sumber daya hutan pada masyarakat Nagari Simanau, Kabupaten Solok. Risalah Kebijakan Pertanian dan Lingkungan, 2(2), 117-128. https://doi.org/10.20957/jkebijakan.v2i2.10 979

Hermayulis, H. (2002). Pengaruh perubahan penguasaan tanah dan susunan pemerintahan di daerah terhadap hubungan kekerabatan matrilineal Minangkabau. Jurnal Hukum \& Pembangunan, 32(4), 376-395. http://dx.doi.org/10.21143/jhp.vol32.no4.1 357

Jaenudin, U., \& Tahrir, T. (2019). Studi religiusitas, budaya sunda, dan perilaku moral pada masyarakat kabupaten Bandung. JPIB : Jurnal Psikologi Islam dan Budaya, 2(1), 1-8. https://doi.org/10.15575/jpib.v2i1.3445

Kandori, M. (1992). Social norms and community enforcement. The Review of Economic Studies, 59(1), 63-80. https://doi.org/10.2307/2297925

Karney, B. R., McNulty, J. K., \& Bradbury, T. N. (2003). Cognition and the development 
of close relationships. Dalam G. Fletcher \& M. Clark (Eds.), Blackwell handbook of social psychology: Interpersonal processes (hal. 32-59). Blackwell Publishing.

Kosasih, A. (2013). Upaya penerapan nilai-nilai adat dan syarak dalam penyelenggaraan pemerintahan nagari. Humanus, 12(2), 107-119.

https://doi.org/10.24036/jh.v12i2.4030

Koskei, B., \& Simiyu, C. (2015). Role of interviews, observation, pitfalls and ethical issues in qualitative research methods. Journal of Educational Policy and Entrepreneurial Research, 2(3), 108-117.

Lauer, M., \& Aswani, S. (2009). Indigenous ecological knowledge as situated practices: Understanding fishers' knowledge in the Western Solomon Islands. American Anthropologist, 111(3), 317-329. https://doi.org/10.1111/j.15481433.2009.01135.x

Liang, Q., Huang, Z., Lu, H., \& Wang, X. (2015). Social capital, member participation, and cooperative performance: Evidence from China's Zhejiang. International Food and Agribusiness Management Review, 18(1), 49-77.

http://dx.doi.org/10.22004/ag.econ.197768

Mackie, G., Moneti, F., Shakya, H., \& Denny, E. (2014). What are social norms? How are they measured. UNICEF/ University of California, San Diego, Center on Global Justice.

Magno, F. (2001). Forest devolution and social capital: State-civil society in the Philippines. Environmental History, 6(2), 264-286. https://doi.org/10.2307/3985087

Martial, T. (2011). Studi empiris dan implikasi penerapan konsep "tree tenure" di Sumatera Barat. MIMBAR, Jurnal Sosial dan Pembangunan, 27(2), 133-142. https://doi.org/10.29313/mimbar.v27i2.321

Martial, T., Helmi, Effendi, N., \& Martius, E. (2012). Land and tree tenure rights on agroforestry (parak) system at communal land in West Sumatra, Indonesia. Journal of Agricultural Extension and Rural Development, 4(19), 486-494. https://doi.org/10.5897/JAERD11.120

Michon, G., Mary, F., \& Bompard, J. (1986). Multistoried agroforestry garden system in West Sumatra, Indonesia. Agroforestry Systems, 4(4), 315-338. https://doi.org/10.1007/bf00048106

Mistry, J., \& Berardi, A. (2016). Bridging indigenous and scientific knowledge. Science, 352(6291), 1274-1275. https://doi.org/10.1126/science.aaf1160

Moravcsik, A. (2014). Transparency: The revolution in qualitative research. $P S$ : Political Science \& Politics, 47(1), 48-53. https://doi.org/10.1017/S10490965130017 89

Mulyana, A., Iskandarsyah, A., Siswadi, A. G. P., \& Srisayekti, W. (2019). Social value orientation on corruption prisoners. MIMBAR: Jurnal Sosial dan Pembangunan, 35(1), 245-252. https://doi.org/10.29313/mimbar.v35i1.447 9

Nababan, E. J. K., Qurniati, R., \& Kustanti, A. (2016). Modal sosial pada pengelolaan dan pelestarian hutan mangrove di Kecamatan Labuhan Maringgai Kabupaten Lampung Timur. Jurnal Sylva Lestari, 4(2), 89-100. https://doi.org/10.1017/CBO97811074153 24.004

Nath, T. K., Inoue, M., \& Pretty, J. (2010). Formation and function of social capital for forest resource management and the improved livelihoods of indigeneous people in Bangladesh. Journal of Rural and Community Development, 3, 104-122.

Nescolarde-Selva, J. A., Usó-Doménech, J.-L., \& Gash, H. (2017). What are ideological systems? Systems, 5(1), 1-17. https://doi.org/10.3390/systems5010021

Nursidah, N., Nugroho, B., Darusman, D., Rusdiana, O., \& Rasyid, Y. (2012). Institutional development to build a succesfull local collective action in forest management from Arau watershed unit management area, West Sumatera. Jurnal 
Manajemen Hutan Tropika (Journal of Tropical Forest Management), 18(1), 1830. https://doi.org/10.7226/jtfm.18.1.18

Octavia, D., \& Rachmat, H. H. (2020). Promoting agroforestry model in increasing land cover to sustain community livelihood in Paru Village Forest. IOP Conf. Series: Earth and Environmental Science, 449, 012011. https://doi.org/10.1088/17551315/449/1/012011

Oki, A. (1984). The dynamics of subsistence economy in West Sumatra. SENRI Ethnological Studies, 13, 267-291.

Ortiz, B., Donate, M. J., \& Guadamillas, F. (2016). Relational and cognitive social capital: Their influence on strategies of external knowledge acquisition. Procedia Computer Science, 99, 91-100. https://doi.org/10.1016/j.procs.2016.09.103

Otsuka, M. (2009). Impacts of farmers' land use on natural forest conversion: A case study from West Sumatra, Indonesia. Tropics, 18(3), 155-166. https://doi.org/10.3759/tropics.18.155

Oun, M. A., \& Bach, C. (2014). Qualitative research method summary. Journal of Multidisciplinary Engineering Science and Technology (JMEST), 1(5), 252-258.

Owen, G. T. (2014). Qualitative methods in higher education policy analysis: Using interviews and document analysis. The Qualitative Report, 19(52), 1-19.

Payne, G. T., Moore, C. B., Griffis, S. E., \& Autry, C. W. (2011). Multilevel challenges and opportunities in social capital research. Journal of Management, 37(2), 491-520. https://doi.org/10.1177/014920631037241 3

Qu, S., \& Dumay, J. (2011). The qualitative research interview. Qualitative Research in Accounting and Management, 8(3), 238264.

https://doi.org/10.1108/117660911111620 70

Ramón-Hidalgo, A.-E., Kozak, R. A., Harshaw, H. W., \& Tindall, D. B. (2018).
Differential effects of cognitive and structural social capital on empowerment in two community ecotourism projects in Ghana. Society \& Natural Resources, 31(1), 57-73. https://doi.org/10.1080/08941920.2017.13 64454

Rangkoto, N. M. (1982). Pantun adat Minangkabau. Balai Pustaka.

Robinson, M. D., \& Clore, G. L. (2002). Belief and feeling: Evidence for an accessibility model of emotional self-report. Psychological Bulletin, 128(6), 934-960. https://doi.org/10.1037/0033-

2909.128.6.934

Roslinda, E., Ekyastuti, W., \& Kartikawati, S. M. (2017). Social capital of community forest management on Nusapati village, Mempawah District, West Kalimantan, Indonesia. Biodiversitas Journal of Biological Diversity, 18(2), 548-554. https://doi.org/10.13057/biodiv/d180215

Rozi, S. (2017). Local wisdom and natural disaster. El Harakah, 19(1), 1-19. https://doi.org/10.18860/el.v19i1.3952

Ruff, C. C., Ugazio, G., \& Fehr, E. (2013). Changing social norm compliance with noninvasive brain stimulation. Science, 342(6157), 482-484. https://doi.org/10.1126/science.1241399

Safitri, I., Winarso, H., \& Zulkaidi, D. (2016). The transformation of Nagari (village) Kurai V Jorong into Bukittinggi city, Indonesia. Dalam I. Ngah \& K. H. Kamarudin (Eds.), Advancing inclusive rural development and transformation in a challenging environment (hal. 529-537). Universiti Teknologi Malaysia.

Santhyami, Basukriadi, A., Patria, M. P., \& Abdulhadi, R. (2018). The comparison of aboveground $\mathrm{C}$-stock between cocoa-based agroforestry system and cocoa monoculture practice in West Sumatra, Indonesia. Biodiversitas, 19(2), 472-479. https://doi.org/10.13057/biodiv/d190214

Schumpeter, J. (1909). On the concept of social value. The Quarterly Journal of 
Economics, 23(2), 213-232. https://doi.org/10.2307/1882798

Schwartz, S. H. (1992). Universals in the content and structure of values: Theoretical advances and empirical tests in 20 countries. Advances in Experimental Social Psychology, 25(1), 1-65. https://doi.org/10.1016/s00652601(08)60281-6

Schwartz, S. H. (2012). An overview of the Schwartz theory of basic values. Online Readings in Psychology and Culture, 2(1). https://doi.org/10.9707/2307-0919.1116

Stark, A. (2014). Sometimes the government must solve the case: The example of a Minangkabau land conflict. American Journal of Humanities and Social Sciences, 2(2), 111-116. http://dx.doi.org/10.11634\%2F232907811 402523

Suharjito, D. (2014). Pengantar metode penelitian. PT Penerbit IPB Press.

Sumilia, S., Akhir, N., \& Syarif, Z. (2019). Plant diversity in various agroforestry system based on cocoa in Pasaman, West Sumatra. International Journal of Environment, Agriculture and Biotechnology, 4(2), 402-406. https://doi.org/10.22161/ijeab/4.2.22

Sweetman, J., Maio, G. R., Spears, R., Manstead, A. S. R., \& Livingstone, A. G. (2019). Attitude toward protest uniquely predicts (normative and nonnormative) political action by (advantaged and disadvantaged) group members. Journal of Experimental Social Psychology, 82, 115128.

http://dx.doi.org/10.1016\%2Fj.jesp.2019.0 1.001

Szulecka, J., \& Secco, L. (2014). Local institutions, social capital and their role in forest plantation governance: Lessons from two case studies of smallholder plantations in Paraguay. International Forestry Review, 16(2), 180-190. https://doi.org/10.1505/146554814811724 810
Tanjung, N. S., Sadono, D., \& Wibowo, C. T. (2017). Tingkat partisipasi masyarakat dalam pengelolaan hutan nagari di Sumatera Barat. Jurnal Penyuluhan, 13(1), 14-30.

https://doi.org/10.25015/penyuluhan.v13i1. 12990

Tasri, E. S., Muslim, I., \& Karimi, K. (2020). The effect of economic factors on the level of disasters that occur in the area of West Sumatra. IOP Conference Series: Earth and Environmental Science, 485(1), 1-10. https://doi.org/10.1088/17551315/485/1/012110

Teilmann, K. (2012). Measuring social capital accumulation in rural development. Journal of Rural Studies, 28(4), 458-465. https://doi.org/10.1016/j.jrurstud.2012.10.0 02

Tono, S., Syibly, M. R., Mu'allim, A., Nurozi, A., \& Purwanto, M. R. (2019). The harmonious relationship between Minangkabau custom and Islam in the distribution of inheritance. Al-Shajarah: Journal of the International Institute of Islamic Thought and Civilization (ISTAC), 39-55..

Tsirogianni, S., \& Gaskell, G. (2011). The role of plurality and context in social values. Journal for the Theory of Social Behaviour, 41(4), 441-465. http://dx.doi.org/10.1111\%2Fj.14685914.2011.00470.x

Uphoff, N. (2000). Understanding social capital: Learning from the analysis and experience of participation. Dalam P. Dasgupta \& I. Serageldin (Eds.), Social capital: A multifaceted perspective (hal. 215-249). World Bank.

Usó-Doménech, J. L., \& Nescolarde-Selva, J. (2016). What are belief systems? Foundations of Science, 21(1), 147-152. https://doi.org/10.1007/s10699-015-9409-z

Usó-Doménech, Josep Lluis, Nescolarde-Selva, J., \& Gash, H. (2015). Guest editorial: Belief systems and science. Cybernetics and Systems, 46(6-7), 379-389. 
https://doi.org/10.1080/01969722.2015.10 38471

Valsiner, J. (2003). Interaction and development: Accounting for emergence. Dalam C. Raeff \& J. B. Benson (Eds.), Social and cognitive development in the context of individual, social, and cultural processes (hal. 13-34). Routledge Taylor $\&$ Francis Group.

Van Rijn, F., Bulte, E., \& Adekunle, A. (2012). Social capital and agricultural innovation in Sub-Saharan Africa. Agricultural Systems, $\quad 108, \quad 112-122$. https://doi.org/10.1016/j.agsy.2011.12.003

Villamor, G. B., Akiefnawati, R., Van Noordwijk, M., Desrianti, F., \& Pradhan, U. (2015). Land use change and shifts in gender roles in central Sumatra, Indonesia. International Forestry Review, 17(4), 6175.

https://doi.org/10.1505/146554815816086 444

von Benda-Beckmann, F. (2013). Property in social continuity: Continuity and change in the maintenance of property relationships through time in Minangkabau, West Sumatra (Vol. 86). Springer Science \& Business Media.

von Benda-Beckmann, F., \& von BendaBeckmann, K. (2012). Islamic law in a plural context: The struggle over inheritance law in colonial West Sumatra. Journal of the Economic and Social History of the Orient, 55(4-5), 771-793. https://doi.org/10.1163/1568520912341269

Webb, E. L. (2017). Rural household participation in illegal timber felling in a protected area of West Sumatra, Indonesia. Dalam Redefining Diversity \& Dynamics of Natural Resources Management in Asia, Volume 4 (hal. 173-188). Elsevier. https://doi.org/10.1016/b978-0-12-8054512.00014-4

Wicker, A. W. (1969). Attitudes versus actions: The relationship of verbal and overt behavioral responses to attitude objects.
Journal of Social Issues, 25(4), 41-78. https://doi.org/10.1111/j.1540-

4560.1969.tb00619.x

Wilson, V. (2012). Research methods: Interviews. Evidence Based Library and Information Practice, 7(2), 96-98. https://doi.org/10.18438/B89P5B

Wulandari, C., Herwanti, S., \& Febryano, I. G. (2018). Peran kelembagaan nagari dalam pengelolaan hutan di Nagari Sirukam, Kabupaten Solok. Gorontalo Journal of Forestry Research, 1(2), 30-39. https://doi.org/10.32662/gjfr.v1i2.368

Yamaki, K. (2016). Role of social networks in urban forest management collaboration: A case study in northern Japan. Urban Forestry \& Urban Greening, 18, 212-220. https://doi.org/10.1016/j.ufug.2016.06.009 